\title{
Tumbuh Kembang Anak Hipotiroid Kongenital yang Diterapi dini dengan Levo-tiroksin dan Dosis Awal Tinggi
}

\author{
Adi Wirawan, ${ }^{1}$ Sunartini, ${ }^{2}$ Bikin Suryawan, ${ }^{1}$ Soetjiningsih ${ }^{1}$ \\ Bagian/SMF Ilmu Kesehatan Anak Fakultas Kedokteran UNUD- RSUP Sanglah, ${ }^{1}$ \\ Bagian/SMF Ilmu Kesehatan Anak Fakultas Kedokteran UGM- RSUP Dr. Sardjito, Yogyakarta. ${ }^{2}$
}

Latar belakang. Hipotiroid kongenital (HK) adalah penyebab disabilitas intelektual yang bisa dicegah dengan diagnosis dini diikuti dengan pemberian terapi pengganti levo-tiroksin (L-T4). Deteksi dini melalui skrining hipotiroid kongenital ( $\mathrm{SHK}$ ) belum menjadi program rutin pemerintah sehingga kasus $\mathrm{HK}$ belum banyak dapat dikelola secara tepat dan berkesinambungan.

Tujuan. Mengetahui gambaran pencapaian tumbuh kembang anak dengan HK yang mendapat terapi dengan L-T4 pada usia balita.

Metode. Penelitian studi kasus (case study). Pasien HK usia balita yang menjalani terapi LT4 di Poliklinik Endokrin Anak RS Sanglah, RSUD Wangaya Denpasar dan RSUD Karangasem sejak tahun 2006 berdasarkan catatan medik, dianalisis perjalanan penyakit dan terapinya. Dilakukan penilaian tumbuh kembang pada usia balita dengan skala mental dan motor dari Bayley II (BSID II), pertumbuhan dinilai parameter antropometrik berdasarkan WHO Anthro-2005, maturitas tulang dengan bone age.

Hasil. Duabelas kasus dianalisis, terdiri dari 4 laki-laki dan 8 perempuan, usia diagnosis antara 3-18 bulan. Lima subyek dengan HK berat, 4 tidak berat, dan 3 disertai sindrom Down secara klinis. Saat diagnosis ditegakkan, rerata TSH awal adalah 130,73 (SB 194,89) uIU/mL dan rerata FT4 0,54 (SB 0,54) ng/dL, dan dengan rerata BBL 2862,50 (SB 487,16) gram. Lima kasus mendapatkan terapi dini dan 7 kasus dengan terapi tidak dini.

Kesimpulan. Luaran indeks perkembangan psikomotor lebih baik pada HK permanen yang menggunakan dosis awal tinggi dibandingkan dosis standar. Luaran pertumbuhan mengalami perbaikan setelah pemberian terapi L-T4 berdasarkan parameter antropometri. Percepatan pertumbuhan pada usia balita akan tercapai apabila diterapi sejak dini. Sari Pediatri 2013;15(2):69-74.

Kata kunci: hipotiroid kongenital, tumbuh kembang, balita

\footnotetext{
Alamat korespondensi:

Dr. I Ketut Adi Wirawan. Bagian/SMF Ilmu Kesehatan Anak FK UNUD/RSUP Sanglah Denpasar. Jln. Pulau Nias Denpasar Bali. Telepon/Fax: 0361-244038 atau 0361-257387 E-mail:adiwirawan59@ yahoo.com
}

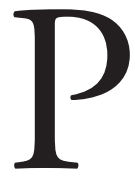
embangunan nasional dibidang kesehatan dengan paradigma sehat menekankan upaya promotif dan preventif dalam upaya pembangunan manusia Indonesia seutuhnya. 
Upaya tersebut diselenggarakan melalui upaya kesehatan anak yang dilakukan sedini mungkin sejak anak masih dalam kandungan sampai lima tahun pertama kehidupan. Tujuannya adalah mempertahankan hidup sekaligus meningkatkan kualitas hidup anak agar mencapai tumbuh kembang optimal baik fisik, mental, emosional, sosial, serta memiliki intelegensi majemuk sesuai potensi genetiknya ${ }^{1}$

Masa tiga tahun pertama kehidupan adalah periode kritis tumbuh kembang anak. Pencegahan penyimpangan perkembangan dilakukan dengan mengoptimalkan perkembangan anak pada periode ini melalui deteksi gangguan tumbuh kembang anak dan stimulasi dini. Masalah tumbuh kembang anak yang sering dijumpai memerlukan perhatian, antara lain kurang energi protein (KEP), obesitas, kretin atau hipotiroid kongenital, disabilitas intelektual, palsi serebral, gangguan bicara, dan lain sebagainya. ${ }^{2}$

Hipotiroid kongenital ( $\mathrm{HK}$ ) adalah penyebab disabilitas intelektual yang bisa dicegah dengan diagnosis dini, kemudian diberikan terapi pengganti dengan levo-tiroksin (L-T4). Deteksi dini melalui skrining hipotiroid kongenital (SHK) belum menjadi program rutin pemerintah sehingga kasus HK belum banyak dapat dikelola secara tepat dan berkesinambungan. 3,4

Penelitian ini bertujuan untuk mendapatkan gambaran luaran tumbuh kembang anak dengan $\mathrm{HK}$ yang sedang menjalani terapi dini dan dosis awal tinggi dengan L-T4, pada usia balita

\section{Metode}

Penelitian kualitatif dengan rancang penelitian studi kasus (case study). Penelitian dilaksanakan di poliklinik anak RSUP Sanglah, Rumah Sakit Umum Wangaya Denpasar dan Rumah Sakit Umum Karangasem. Sampel penelitian adalah semua balita dengan HK yang mendapat terapi L-T4 sejak tahun 2006-2011 dan orangtua setuju dan menandatangani persetujuan setelah penjelasan (PSP).

Hipotiroid kongenital didefinisikan sebagai penyakit defisiensi hormon tiroid yang bersifat kongenital, berdasarkan klinis dan laboratorium microparticel enzyme immunoassay (MEIA) yang menunjukkan penurunan hormon tiroid kadar FT4 $<0,9 \mathrm{ng} / \mathrm{dL}$, dan/atau peningkatan $\mathrm{TSH}>20 \mu \mathrm{IU} /$ $\mathrm{mL}$ ( berdasarkan hasil SHK), atau TSH $>9,1 \mu \mathrm{IU} /$ $\mathrm{mL}$ (diperiksa $>2$ minggu setelah lahir). Hipotiroid kongenital primer apabila kadar TSH $>50 \mu \mathrm{IU} /$ mL, dan HK berat apabila kadar TSH >100 $\mu \mathrm{IU} /$ mL. ${ }^{5,6}$ Gangguan pertumbuhan dinilai berdasarkan pemeriksaan antropometri dan dinilai menggunakan kurva WHO Anthro-2005, sedangkan gangguan perkembangan dinilai berdasarkan skala Bayley (BSID II). Terapi dini apabila anak dengan $\mathrm{HK}$ yang sudah diterapi dengan L-T4 sebelum berusia 6 bulan, dan terapi tidak dini apabila diterapi setelah usia 6 bulan. Dosis obat awal adalah dosis L-T4 yang diberikan pada saat pertama kali setelah diagnosis ditegakkan. Dosis standar adalah apabila dosis awal terapi di bawah $10 \mathrm{ug} / \mathrm{Kg} /$ hari. Dosis tinggi adalah apabila dosis awal terapi $10-15 \mathrm{ug} / \mathrm{Kg} / \mathrm{hari}^{7}$ Maturitas tulang terlambat adalah keterlambatan perkembangan tulang berdasarkan pemeriksaan rontgen tangan kiri, dinilai berdasarkan atlas dari Greulich \& Pyle. Percepatan pertumbuhan dihitung berdasarkan selisih $\mathrm{BB}$ dan PB akhir pengamatan dengan $\mathrm{BB}$ dan PB awal terapi setahun. Penyakit penyerta adalah penyakit lain, atau komorbid yang juga diderita oleh anak dengan HK, misalnya penyakit jantung bawaan, sindrom Down.

Data dasar dikumpulkan secara retrospektif berdasarkan hasil SHK provinsi Bali dari tahun 2007-2010, kemudian divalidasi dari catatan medik perinatologi ketiga rumah sakit tersebut. Data pasien HK berdasarkan temuan klinis, dan mendapatkan terapi L-T4 diperoleh catatan medik poliklinik endokrinologi rumah sakit tersebut.

Luaran perkembangan dinilai berdasarkan skala Bayley (BSID II), luaran mental berdasarkan nilai MDI dan luaran psikomotor berdasarkan nilai PDI, dikerjakan oleh seorang psikolog dari Yogyakarta. Hasil pengamatan dan pengukuran terhadap variabel dan luaran dianalisis untuk dapat ditarik kesimpulan penelitian. Masing-masing kasus dibahas secara lebih mendalam, perjalanan penyakit kasus yang satu dengan yang lain dibandingkan persamaan, maupun perbedaannya sehingga memengaruhi luaran tumbuh kembangnya.

\section{Hasil}

Selama 5 tahun ( 2006-2011) berdasarkan temuan klinis, terdapat 46 anak dengan HK yang menjalani rawat jalan, 34 anak di poli endokrin RSUP Sanglah, dan 12 anak di poli endokrin RSU Wangaya, Denpasar. Dari 46 anak tersebut, 34 di antaranya dieksklusi 
karena 3 anak berusia di atas lima tahun, 1 meninggal karena pneumonia sangat berat, sisanya data yang tidak lengkap. Duabelas anak memenuhi kriteria inklusi untuk dijadikan subyek serial kasus HK. Karakteristik dasar subyek tertera pada Tabel 1 .

Kasus yang dianalisis terdiri dari 4 laki-laki dan 8 perempuan, usia diagnosis antara 3 sampai 18 bulan. Berdasarkan diagnosis 5 subyek dengan HK berat, $4 \mathrm{HK}$ tidak berat, dan $3 \mathrm{HK}$ dengan disertai klinis sindrom Down. Saat diagnosis ditegakkan, rerata TSH awal adalah 130.73 (SB 194,89) $\mu \mathrm{IU} / \mathrm{Ml}$, rerata FT4 $0,54(\mathrm{SB} 0,54) \mathrm{ng} / \mathrm{dL}$, dan rerata BBL 2862.50 (SB 487,16 ) gram. Perbandingan luaran tumbuh kembang kasus berdasarkan usia terapi dan pemberian dosis awal terapi tertera pada Tabel 2 dan 3 di bawah ini.

Perbandingan rerata percepatan pertumbuhan berat badan maupun panjang badan antara yang diterapi sejak dini dengan yang tidak dini (Gambar 1).

Tabel 1. Karakteristik dasar subyek

\begin{tabular}{lcccccl}
\hline No & $\begin{array}{c}\text { Usia } \\
\text { (bulan) }\end{array}$ & L/P & $\begin{array}{c}\text { BBL } \\
\text { (gram) }\end{array}$ & $\begin{array}{c}\text { TSH, } \\
\mathrm{mIU} / \mathrm{ml}\end{array}$ & $\begin{array}{c}\text { FT4, } \\
\mathrm{ng} / \mathrm{dl}\end{array}$ & Gambaran klinis \\
\hline 1 & 4 & $\mathrm{~L}$ & 3500 & 389,09 & 0,04 & malas minum, tumor sub lingual \\
2 & 3 & $\mathrm{P}$ & 3250 & 623,25 & $0,11 \mathrm{ug}(\mathrm{T} 4)$ & $\begin{array}{l}\text { konstipasi, ikterus } \\
3\end{array}$ \\
16 & $\mathrm{P}$ & 3300 & 192,54 & 0,21 & kurus, perkembangan terlambat \\
4 & 7 & $\mathrm{P}$ & 3600 & $>100$ & 0,075 & makroglosia, hernia umbilikalis \\
5 & 7 & $\mathrm{P}$ & 3000 & 114,4 & 0,23 & kurus, perkembangan terlambat \\
6 & 15 & $\mathrm{P}$ & 2000 & 5,96 & 1,05 & mongoloid, simian crease \\
7 & 3 & $\mathrm{P}$ & 2800 & 27,94 & 1,02 & ikterus, mongoloid, simian crease \\
8 & 18 & $\mathrm{P}$ & 2850 & 12,63 & 0,57 & mongoloid, simian crease \\
9 & 3 & $\mathrm{~L}$ & 2200 & 2,13 & 0,64 & makroglosia, hernia umbilikalis \\
10 & 3 & $\mathrm{~L}$ & 2500 & 24,37 & 1,26 & makroglosia, hernia umbilikalis \\
11 & 16 & $\mathrm{~L}$ & 3000 & 32,2 & $8,2(\mathrm{~T} 4)$ & perkembangan terlambat \\
12 & 0 & $\mathrm{P}$ & 2500 & 25,25 & 0,025 & tanpa klinis \\
\hline
\end{tabular}

Tabel 2. Luaran status antropometri dan usia tulang berdasarkan usia terapi dan dosis awal terapi

\begin{tabular}{|c|c|c|c|c|c|c|}
\hline \multirow[t]{2}{*}{ No } & \multirow{2}{*}{$\begin{array}{c}\text { Usia } \\
\text { (bulan) }\end{array}$} & \multirow{2}{*}{$\begin{array}{l}\text { Usia terapi } \\
\text { (bulan) }\end{array}$} & \multirow{2}{*}{$\begin{array}{c}\text { Dosis awal } \\
\text { (ug/KgBB/h) }\end{array}$} & \multicolumn{2}{|c|}{ Status antropometri } & \multirow{2}{*}{$\begin{array}{l}\text { Usia } \\
\text { tulang }\end{array}$} \\
\hline & & & & awal diagnosis & akhir pengamatan & \\
\hline 1 & 29 & 4 & 10 & GT, BBSK, P & normal & terlambat 4 bulan \\
\hline 2 & 39 & 10 & 10 & GT, BBK, SP & GT,BBK, P & terlambat 11 bulan \\
\hline 3 & 41 & 16 & 12 & GT,BBK,P & normal & terlambat 21 bulan \\
\hline 4 & 12 & 7 & 8 & GT,BBK,SP & SP & terlambat 2 bulan \\
\hline 5 & 40 & 7 & 15 & GT, BBSK,SP & $\mathrm{P}$ & sesuai usia \\
\hline 6 & 28 & 15 & 3 & normal & normal & sesuai usia \\
\hline 7 & 13 & 3 & 6 & GT, SP & SP & terlambat 8 bulan \\
\hline 8 & 37 & 18 & 3 & GT, BBSK, SP & SP & terlambat 20 bulan \\
\hline 9 & 12 & 3 & 6 & GT, BBK, SP & $\mathrm{K}, \mathrm{BBK}$ & terlambat 8 bulan \\
\hline 10 & 9 & 3 & 10 & $\mathrm{P}$ & normal & terlambat 3bulan \\
\hline 11 & 41 & 16 & 10 & $\mathrm{P}$ & normal & sesuai usia \\
\hline 12 & 33 & 0 & 10 & normal & normal & sesuai usia \\
\hline
\end{tabular}

Keterangan :

- BBK: Berat badan kurang (underweight)

- BBSK: Berat badan sangat kurang (severely underweight)

- GT: gagal tumbuh

- P: pendek (stunted)

- SP: Sangat pendek (severely stunted)

- K: Kurus (wasted) 
Tabel 3. Luaran perkembangan subyek berdasarkan usia terapi dan dosis awal terapi

\begin{tabular}{|c|c|c|c|c|c|c|c|}
\hline \multirow[b]{2}{*}{ No } & \multirow{2}{*}{$\begin{array}{c}\text { Usia } \\
\text { (bulan) }\end{array}$} & \multirow{2}{*}{$\begin{array}{l}\text { Usia terapi } \\
\text { (bulan) }\end{array}$} & \multirow{2}{*}{$\begin{array}{c}\text { Dosis awal } \\
\text { (ug/KgBB/hari) }\end{array}$} & \multicolumn{2}{|c|}{ BSID II } & \multicolumn{2}{|c|}{ Interpretasi perkembangan } \\
\hline & & & & MDI & PDI & Mental & Psikomotor \\
\hline 1 & 29 & 4 & 10 & 83 & 106 & KR & Normal \\
\hline 2 & 39 & 10 & 10 & 78 & 84 & KR & Normal \\
\hline 3 & 41 & 16 & 12 & 98 & 101 & Normal & Normal \\
\hline 4 & 12 & 7 & 8 & 72 & 53 & KR & $\mathrm{KB}$ \\
\hline 5 & 40 & 7 & 15 & 102 & 101 & Normal & Normal \\
\hline 6 & 28 & 15 & 3 & 51 & 95 & $\mathrm{~KB}$ & Normal \\
\hline 7 & 13 & 3 & 6 & 50 & 50 & $\mathrm{~KB}$ & $\mathrm{~KB}$ \\
\hline 8 & 37 & 18 & 3 & 50 & 51 & $\mathrm{~KB}$ & KB \\
\hline 9 & 12 & 3 & 6 & 71 & 70 & $\mathrm{KR}$ & KR \\
\hline 10 & 9 & 3 & 10 & 82 & 83 & KR & KR \\
\hline 11 & 41 & 16 & 10 & 98 & 105 & normal & normal \\
\hline 12 & 33 & 0 & 10 & 100 & 131 & normal & normal \\
\hline
\end{tabular}

Keterangan

KR: Keterlambatan ringan (Midly delayed performance)

KB: Keterlambatan bermakna (Significanly delayed performance)

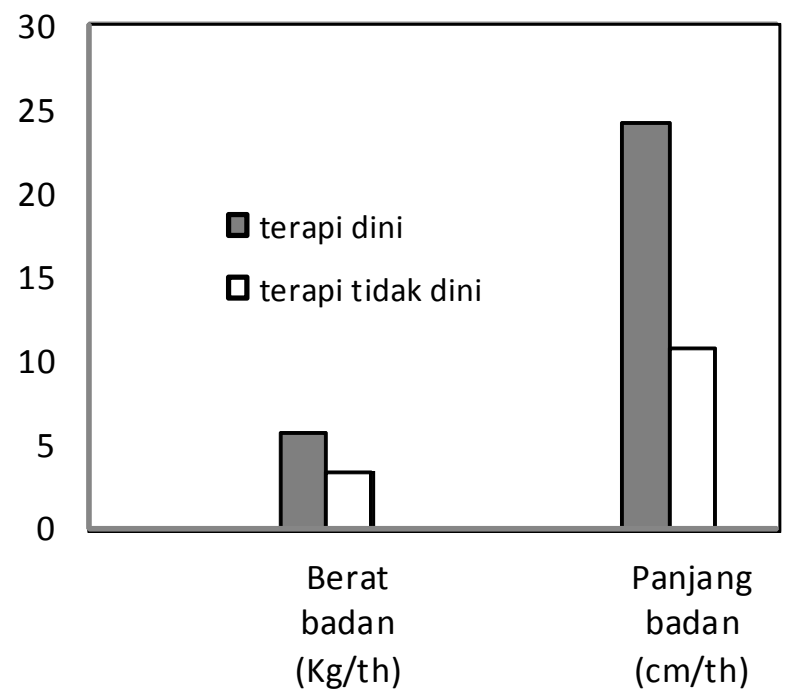

Gambar 1. Rerata percepatan pertumbuhan berdasarkan usia terapi

Gambar 2 menunjukkan perbedaan luaran indeks perkembangan. Pada kasus 1 sampai 5 yang merupakan HK berat setelah terapi tidak tampak perbedaan indeks mental dan psikomotor. Kasus 8 sampai 12 adalah HK tidak berat menunjukkan rerata luaran psikomotor lebih baik dari luaran mental. Kasus 6,7,8 merupakan kasus HK disertai sindrom Down menunjukkan keterlambatan perkembangan bermakna, tetapi skala psikomotor lebih baik dibandingkan skala mentalnya.

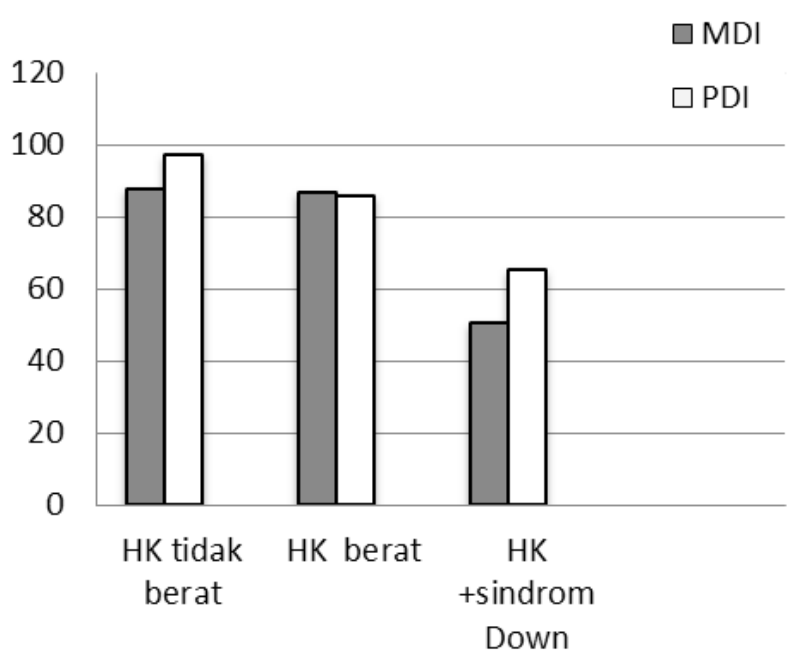

Gambar 2. Luaran rerata perkembangan berdasarkan klasifikasi penyakit

\section{Pembahasan}

Selama 4 tahun dari tahun 2007 sampai 2010 di Bali, terdapat 6347 bayi baru lahir dilakukan skrining HK oleh dinas Kesehatan Provinsi Bali. Duapuluh delapan bayi dinyatakan positif berdasarkan kadar TSH lebih dari $20 \mathrm{uIU} / \mathrm{ml}$ pada dua kali pemeriksaan. Prevalensinya sekitar $4: 1000$. Rerata usia gestasi adalah $38,9 \pm 1,6$ minggu. Rerata berat badan lahir (BBL) bayi $3006 \pm 482,4$ gram, dan rerata kadar TSH 5,58 uIU/ml. 
Sebagian besar, yaitu 17 dari 28 bayi yang dinyatakan positif berasal dari kabupaten Karangasem.

Kabupaten Karangsasem, berdasarkan peta prevalensi GAKY tahun 1998 merupakan daerah endemis sedang, sedangkan Buleleng dan Denpasar termasuk daerah endemis ringan. Beberapa kecamatan di Kabupaten Karangasem, yaitu Kubu, Bebandem, dan Rendang merupakan daerah endemis berat. Jadi perbedaan temuan hasil SHK, sesuai dengan daerah endemis GAKY. ${ }^{8}$

Luaran pertumbuhan berdasarkan status antropometri, secara umum mengalami perbaikan status gizi setelah pemberian terapi L-T4. Perbedaan yang terjadi pada masing-masing kasus adalah pada panjang badan terhadap umur $(\mathrm{PB} / \mathrm{U})$. Faktor yang kemungkinan memengaruhi adalah onset terapi, usia penilaian, komorbid, dan potensi genetik. Pemberian pengobatan yang adekuat sejak usia 46 minggu dapat menjamin pertumbuhan normal dengan tinggi akhir berada dalam rentang \pm 2 SD. Luaran usia tulang mencerminkan lamanya terpapar dengan kondisi hipotiroid, beratnya penyakit, dan komorbid. ${ }^{9}$

Perbandingan luaran tumbuh kembang kasus berdasarkan usia terapi dan pemberian dosis awal terapi. Apabila terapi dilakukan sejak dini, tidak akan ada perbedaan luaran rerata tinggi badan setelah usia 3 tahun. Pertumbuhan linier, maturasi seksual dan tinggi akhir anak HK, yang diterapi sejak dini tidak berbeda dengan anak normal. Faktor utama untuk tinggi badan untuk anak ini adalah potensi genetik keluarga ${ }^{10}$

Pada kasus HK disertai sindrom Down menunjukkan keterlambatan perkembangan bermakna, tetapi skala psikomotor lebih baik dibandingkan skala mentalnya. Jadi pada kasus HK dengan sindrom Down perbaikannya terutama pada psikomotor. Salerno $\mathrm{dkk}^{10}$ mendapatkan tidak didapatkan perbedaan yang bermakna luaran intelektual antara HK berat dengan HK sedang, jika diberikan terapi sejak dini dengan dosis awal tinggi.

Kasus 1,2,3,4, dan 5 adalah kasus HK permanen yang berat, perbedaan luaran tumbuh-kembangnya, kemungkinan disebabkan oleh perbedaan mulai terapi, dosis awal dan keteraturan yang menjamin keadekuatan terapi dan juga bisa karena perbedaan beratnya penyakit diamati dari kadar TSH atau FT4 saat awal diagnosis. Mempertahankan kadar TSH dan FT4 dalam rentang normal dalam 6 bulan pertama kehidupan, juga memengaruhi luaran jangka panjang. ${ }^{11}$
Dari kelima kasus HK berat tersebut, yang dapat dilihat persamaannya adalah, pemberian dosis awal tinggi (kasus 1,2,3,5), pencapaian indeks perkembangan psikomotor lebih baik dibandingkan dengan pemberian dosis standar (kasus 4). Dengan dosis awal L-T4 yang lebih tinggi diharapkan kondisi eutiroid akan lebih cepat tercapai sehingga luaran neurodevelomental akan lebih baik dan luaran intelektual juga akan lebih baik pada usia 4 tahun. ${ }^{7,10,12}$ Terdapat hubungan yang positif antara tingginya dosis awal, dan jumlah kunjungan klinik pada tahun pertama kehidupan, dengan luaran perkembangan intelektual penderita. ${ }^{13}$

Balhara $\mathrm{dkk}^{11}$ menyatakan bahwa beratnya HK, berdasarkan tingkat TSH awal, memerlukan pemantauan rutin tiap bulan sampai 6 bulan kedua terapi, untuk mempertahankan kadarnya sesuai target harapan. Kondisi ini berkaitan erat dengan peran tiroksin terhadap pertumbuhan otak pada periode kritis tumbuh kembang anak. Heyerdahl $\mathrm{dkk}^{14}$ menyatakan kadar T4 dalam 2 tahun pertama kehidupan berkorelasi dengan indeks perkembangan mental pada usia 2 tahun dan kemampuan verbal pada usia 6 tahun.

Nakamizo ${ }^{13}$ dengan penelitian time series menyimpulkan ada tiga faktor yang sangat mempengaruhi buruknya prognosis perkembangan intelektual, yaitu berat badan lahir rendah, komorbiditas, dan tingginya kadar TSH pada saat diagnosis. Berat badan lahir rendah dan komorbid mungkin saling mempengaruhi perkembangan intelektual, sedangkan abnormalitas fungsi tiroid berdiri sendiri. Penelitian juga menyatakan bahwa penundaan pemberian terapi pada penderita HK bukanlah salah satu faktor mayor yang menentukan prognosis intelektual. Faktor mayor lainnya yang juga memegang peran penting adalah terapi yang adekuat dan rutin pada masa-masa balita.

Kelemahan penelitian merupakan penelitian studi kasus kualitatif, dengan jumlah kasus terbatas, tidak semua kasus mendapat terapi dini dan dosis awal tinggi karena menggunakan data retrospektif. Pemilihan kasus yang terbatas memungkinkan pula terjadi bias seleksi, dan tidak terkontrol.

\section{Kesimpulan}

Terapi HK sejak dini diyakini akan memberikan 
luaran pertumbuhan dan perkembangan intelektual yang lebih baik. Beberapa kondisi yang juga mungkin berperan terhadap luaran tumbuh kembang pada balita dengan HK adalah derajat beratnya penyakit, ada tidaknya komorbid, dan keadekuatan terapi L-T4 yang diberikan, meliputi dosis awal yang tinggi, dan keteraturan minum obat, serta ketaatan kunjungan. Indeks perkembangan psikomotor lebih baik pada HK berat yang menggunakan dosis awal tinggi dibandingkan dosis standar.

Berdasarkan penelitian disarankan program SHK diteruskan menjadi program rutin dan hasilnya ditindaklanjuti dengan segera memberi terapi dini dan dosis awal yang tinggi, untuk mencegah disabilitas intelektual.

\section{Daftar pustaka}

1. Departemen Kesehatan RI. Indonesia Sehat 2010, Visi Baru, Misi, Kebijakan dan Strategi Pembangunan Kesehatan. Jakarta. Depkes RI.2000.

2. Soetjiningsih. Kretin. Dalam: Ranuh IGN Gde, Penyunting. Tumbuh Kembang Anak.Jakarta: EGC; 1995. h. 203-10.

3. Rose RS. Update of Newborn Screening and Therapy for Congenital Hypothyroidism. Pediatrics. 2006;117:2290303.

4. Sunartini. Neonatal screening for congenital hypothyroidism: Prevention of mental retardation in children. Proceedings of the 17th Asean Conference on Mental Retardation. Yogyakarta 2005.

5. DiGeorge AM, LaFranchi S. Kelainan Kelenjar Tiroid, Dalam: Behrman RE, Kliegman,RM, Arvin A, Penyunting. Nelson Ilmu Kesehatan Anak. Jakarta: EGC; 2000.h.1935-44.
6. MacGillivray MH. Congenital Hypothyroidism. Dalam: Pescovitz, OH, Eugster, EA, Penyunting. Pediatric Endrokrinology: Mechanisms, Manifestations, and Management. Lippincott Williams \& Wilkins, Philadhelpia; 2004. h 490-507.

7. $\mathrm{Ng} \mathrm{SM}$, Anand D, Weindling AM. High versus low dose of initial thyroid hormone replacement for congenital hypothyroidism (Reviews). The Cochrane Collaboration. Willey.2009;I:1-17.

8. Departemen Kesehatan RI, Peta prevalensi Gondok di Indonesia tahun 1998. Jakarta.Depkes RI.1999.

9. Susanto R, Julia M. Gangguan kelenjar tiroid. Dalam: Batubara JRL, Trijaja B, Pulungan A B, Penyunting. Buku Ajar Endokrinologi anak, IDAI,Sagung Seto, Jakarta; 2010. h.205-21.

10. Salerno M, Militerni R, Bravaccio C, Micillo M, Capalbo D, Di Maio S, et al. Effect of Different Starting Doses of Levothyroxine on Growth and Intellectual Outcome at Four Years of Age in Congenital Hypothyroidism. J Pediatr 2011;141:786-92.

11. Balhara B, Madhusmita M, Levitsky LL. Clinical Monitoring Guidelines for Congenital Hypothyroidism: Laboratory Outcome Data in the First Year of Life J Pediatr. 2011;158:532-7.

12. Selva KA, Harper A, Downs A, Blasco A. Neurodevelopmental outcomes in congenital hipothyroidsm comparison of initial T4 dose and time to reach target T4 and TSH. J Pediatr. 2005;147:775-80.

13. Nakamizo M, Toyabe SI, Asami T, Akazawa K. Mental Development of Infants With Congenital Hypothyroidism: A Longitudinal Study. Clin pediatr. 2007;46:53-8.

14. Heyerdahl S, Kase BF, Lie SO. Intelectual developmental in children with congenital hypothyroidsm in relation to recommended thyroxine treatment. J Pediatr.1991; 118:850-7. 